\title{
Lumen
}

Selected Proceedings from the Canadian Society for Eighteenth-Century Studies

\section{Nahum Tate's ('aberrant/ 'appalling') The History of King Lear [1681]: Lear as Inscriptive Site}

\section{John Rempel}

Volume 17, 1998

Theatre of the world

Théâtre du monde

URI : https://id.erudit.org/iderudit/1012380ar

DOI : https://doi.org/10.7202/1012380ar

Aller au sommaire du numéro

Éditeur(s)

Canadian Society for Eighteenth-Century Studies / Société canadienne d'étude du dix-huitième siècle

ISSN

1209-3696 (imprimé)

1927-8284 (numérique)

Découvrir la revue

Citer cet article

Rempel, J. (1998). Nahum Tate's ('aberrant/ 'appalling') The History of King Lear [1681]: Lear as Inscriptive Site. Lumen, 17, 51-61.

https://doi.org/10.7202/1012380ar

Copyright (c) Canadian Society for Eighteenth-Century Studies / Sociéte canadienne d'étude du dix-huitième siècle, 1998
Ce document est protégé par la loi sur le droit d'auteur. L'utilisation des services d'Érudit (y compris la reproduction) est assujettie à sa politique d'utilisation que vous pouvez consulter en ligne.

https://apropos.erudit.org/fr/usagers/politique-dutilisation/ 


\section{Nahum Tate's ('aberrant,' 'appalling') The History of King Lear [1681]: Lear as Inscriptive Site}

From Addison in 1711 ('as it is reformed according to the chimerical notion of poetical justice, in my humble opinion it has lost half its beauty') to Michael Dobson in 1992 (Shakespeare 'serves for Tate ... as a stalking-horse for the topicality of his adaptations'), Tate's version of Shakespeare's Lear (c.1606) has borne little but slings and arrows. ${ }^{1}$ James Black points out that Tate's version 'has long had far more critics than readers,' and Johnson's famous comment on Congreve's Incognita also applies to Tate's play: 'I would rather praise it than read it,' varying his verb to 'damn.' ${ }^{2}$ Although no one would select his script for desert island reading over Shakespeare's, I believe that Tate is a more innovative, sometimes imaginative, reviser of the Shakespearean play than has been thought. Since treatments of the Lear story form a continuum, extending from the twelfth century to Jane Smiley's A Thousand Acres (1991) and beyond, it is not simply a question of Tate travestying Shakespeare's tragedy by revising it into a romance. ${ }^{3}$ Tate's version is frequently used as a convenient opposite pole compared to Shakespeare's exemplification of high canonical art: thus Gordon Jones characteristically cites Tate as a handy parallel to Elijah Moshinsky's 'abbreviated, simplified, schematised, and vulgarised adaptations of the Shakespearean originals' for the BBC. ${ }^{4}$

Tate's play as well as its immediate source in Shakespeare are both extreme instances of Jerome McGann's generalization that 'every text has variants of itself screaming to get out, or antithetical texts waiting to make themselves known.' 'These variants and antitheses,' McGann continues, 'appear (and multiply) over time, as the hidden features of the textual media are developed and made explicit. ${ }^{5}$ Thus at first invisible in Shakespeare's Lear but becoming visible is the Restoration's need for a version which is both variant and antithesis. In the specific context of stage performance, J. S. Bratton writes that 'there is no one play, Shakespeare's King Lear; rather it is a huge dramatic possibility ... a series of 
plays, some so unalike as to have near-independent existences, have been created. ${ }^{6}$ Similarly, Tate sees the Shakespearean script of the Lear story as a text open to adaptation, not as a monument to be revered or as a script to be produced within its own textual borders, not as a text in the etymological sense of 'to read [to advise, to interpret]' but as a site for writing ['to incise, to mark a surface']. My aim here is to counter the traditional indignant attacks on Tate with a consideration of how, in the sweep of the history of the Lear story, he alters the script which comes down to him. Tate's version was only gradually replaced in the course of the nineteenth century, and here and there I agree with a century and a half's worth of audiences, that he sometimes alters in the direction of theatrical effectiveness. As was Shakespeare's own habitual practice, Tate seized what he found effective in an earlier site, radically revised the materials to suit his vision, and rejected the rest.

His changes are summarized by Doris Adler:

the love story between Edgar and Cordelia, a civil war instead of an invasion, the omission of the Fool, Edmund's attempt on Cordelia's virtue, Regan's rendezvous with Edmund while Cornwall is dying, the sisters' poisoning each other during a banquet, the rescue of Cordelia and Lear, and the restoration of the crown to Lear; the consolidation and reordering of many scenes, particularly those following Lear's flight to the heath, and, of course, the happy ending. ${ }^{7}$

Tate's other changes do not all aim towards one end. Politically, 'Tate ... avoid[ed] any suggestion of the intervention of France in an English sovereignty dispute; he therefore wrote out the King of France, and stressed Gloucester and Lear as leaders in a civil rebellion against the new regime. ${ }^{8}$ Theatrically, since Tate's script cuts the Fool, it renders any Fool/Cordelia doubling impossible; it substitutes onstage presence and dialogue for Shakespeare's verbal reminders of Cordelia (giving her a decent part, as opposed to Shakespeare, where she has only four scenes, and is dead in the climactic section of the last); and it allows the retirement of Lear, Gloucester, and Kent 'to some cool cell' ${ }^{\prime 9}$ while retaining the Edgar disguise as Bedlam beggar. Despite the orthodox view that Tate was at pains to make the play more plausible or less unlikely, he lets stand the most blatant contradiction in Shakespeare's script, the fact that Edgar hears himself 'proclaimed, / And in the happy [Tate has 'friendly'] hollow of a tree / Escaped the hunt' (2.3.1-3), this in a landscape where 'For [Tate adds 'many'] miles about / There's scarce a bush' (2.4.303-04).

A number of commentators on Tate's version are unaware that it was not Tate but Shakespeare who most radically transformed previous tellings of Lear. Thus D.C. Greetham, ironically enough in his Textual 
Scholarship, writes that 'the real ending [sic] of Lear was still preserved in contemporary editions. ${ }^{10}$ This attitude is common in criticism of Tate: by definition, what is Shakespearean is 'real. ${ }^{11}$ Yet Shakespeare's first audience at the Globe (especially those who had seen, a generation before in the late 1580's, the earlier play The True Chronicle History of King Leir) will have been shocked to find themselves viewing a tragedy. It was Shakespeare who transformed the genre of 'chronicle history,' a 'true' play which ends happily, into tragedy, and Tate who restored the older romance genre. Tate's notorious happy ending is found not only in Geoffrey of Monmouth's original narrative in the Historia Regum Britanniae (c. 1136) and in Holinshed's Chronicles, but also in the anonymous True Chronicle. There, Leir and the Kent character meet Cordella [sic] in France, and 'the Gallian King invades England and restores Leir to his throne. ${ }^{12}$ Although Tate is frequently reviled for writing a version so topical and schematic as to be suited only to the Restoration, it is more accurate to see Shakespeare's re-vision of the story - especially the Folio version - as a gory spectacle contrived for Jacobean audiences with a taste for madness, brutality, and horror. ${ }^{13}$

Doris Adler provides the two adjectives of my title in arguing the thesis that 'Tate's Lear must have served some deep, enduring need, for it still breathes with a faint half-life in present productions' (52). She examines 'problems and potentials in Shakespeare's text' and also considers the question of stage tradition, the 'deeply conservative' 'oral tradition perpetuated in unquestioned ... theatrical habits' (52) She affirms that from the point of view of both the audience and of the performers the script needs 'Tate's consolidation and rearrangement of [the] fourteen scenes of acts three and four' and that they 'have been tacitly accepted with few protests from audiences or critics' (54) Her argument is convincing; the Granada Olivier Lear (1983) cuts only three whole scenes, all cuts by Tate three centuries before.

Tate, coming to the script he inherits, finds Shakespearean confusion: a 'heap of jewels, unstrung and unpolished, yet so dazzling in their disorder that I soon perceived I had seized a treasure' (1). The extreme clarity of the oppositions in Tate's metaphors applies to his revisions which do, in general, clarify the unexplained and stress extreme states rather than process: jewels, but the stones unstrung, the gold and silver unpolished, a pointedly alliterative 'dazzling' 'disorder,' the play a 'treasure' which he has 'seized' (anticipating Sam Johnson's metaphor for Shakespeare as a 'mine which contains gold and diamonds in unexhaustible plenty, though clouded by incrustations, debased by impurities, and mingled with a mass of meaner minerals.' $)^{14}$ Tate builds on the site of an earlier text as churches and theatres have been built on earlier sites. 
Critics have contextualized Tate's version in various ways: as philosophical and political rewriting, and as esthetic revision, especially as he rewrites towards classical unities. His play as cultural artifact is parallel to other late seventeenth-century structures, to what Sprat built in his History of the Royal Society, what Wren was building after the Great Fire, and what Locke built in putting 'wit' (involving all forms of combining ideas via metaphor) a pronounced second to 'judgement' (involving discriminating among similar ideas). Thus Jean Marsden quotes Bacon's The New Organon (on how words lead us into 'idle fancies'), concluding that '[Tate's] need to clarify Shakespeare's language bespeaks a profound distrust of language.' But this involves her in two assumptions: first, that Shakespeare's language is necessarily obscure, and second, that Tate 'map[s] out the meaning of each passage. ${ }^{15}$

While it is true that Shakespeare tends not to clearly motivate his characters and that he also frequently makes this very point one of the mysteries of his plays - Iago's lack of promotion, Edmund's lack of land, Cordelia's lack of words of love, all fail spectacularly to account for these characters - nevertheless such a generalization should not combine with our familiarity with the contrast between Shakespeare's metaphorical indeterminacy and his contemporaries' explicitness to make us think that Shakespeare is everywhere gratifyingly obscure and Tate everywhere idiotically precise. Marsden is only one of recent critics who accuse Tate of reducing a complex text to a simple, clear script, of merely 'mapping out meanings,' ironically a literal description of the first error Lear himself commits with his schematically clear intention to divide the kingdom: 'Give me the map there' (1.1.37). The effects of Tate's stringing his 'heap of jewels' may be examined in his transformation of the characterization of Regan, especially in how her part is handled in the blinding of Gloucester scene, and in Tate's rewriting of Shakespeare's treatment of Edmund between his mortal wound and his death.

Tate realizes that the Goneril-Regan conflict is crucial to the development of the drama. In performing Shakespeare's play - a typical example is the BBC film with Michael Hordern as Lear ${ }^{16}$ - Regan's very first lines are often preceded by the stage business of her powerful impulse to speak, which is suddenly closed off by Lear with his 'Goneril, / Our eldest born, speak first' (1.1.53-54; identical in Tate) so that Regan has already become silenced before her first words:

I am made of that self mettle as my sister,

And prize me at her worth. In my true heart

I find she names my very deed of love;

Only she comes too short [my emphasis], that I profess

Myself an enemy to all other joys (1.1.69-73). 
Tate has her say:

My sister, sir, in part expressed my love,

For such as hers is mine, though more extended:

Sense has no other joy that I can relish,

I have my all in my dear liege's love! (1.1.86-89).

Tate does not merely 'clarify,' as Marsden asserts, for his 'in part' is highly multivalent ('true, it was, very understandably, partial, for she spoke first, but it was a good attempt, though necessarily imperfect'). This is not a simplification but a complication of the dramatic situation, for while Shakespeare wants the audience to see the knives out with Regan's 'Only [Goneril] comes too short,' Tate stresses the complexity of the self-conscious verbal role-playing which arises from the dramatic situation: the elder sisters are in a lying contest with one another in front of the court, both knowing that Cordelia, who will tell her version of the truth, will lose. Shakespeare's Regan does have 'other joys' (73) although she proclaims herself an enemy to them; Tate's Regan, with her 'Sense has no other joy that I can relish' reaches a singlemindedly perverse proclamation of her allegiance to her father which Shakespeare's vision does not approach.

In the course of the standard argument that Tate's 'evil characters' have a greater 'program of villainy' than do Shakespeare's characters, Black is dismayed by the fact that in Tate 'Regan dallies with Edmund while her husband is dying, compounding the evil by wishing that he would die quickly' (xxiii). This dismay involves the mediating Gloucester sub-plot, the most horrifying scene of which (3.7) enacts in front of our eyes the blinding of a character not much better or worse than most of us. At this point the servant has intervened, wounding Cornwall, and is killed by Regan - and at Cornwall's 'Regan, I bleed apace. / Untimely comes this hurt. Give me your arm' (3.7.100-01) there is no indication in Shakespeare that she follows his directions, and accordingly, Tate revises so that after the Duke's 'Regan, I bleed apace, give me your arm,' the stage direction simply reads 'Exeunt.' It is not Tate but rather David Bevington (in his Complete Works, 1992) who desires Regan to be lovingly supportive: 'Exeunt [Cornwall, supported by Regan]' (1201).

Tate's version does not merely make Regan more evil: no commentator on Tate's Lear notes that Shakespeare's beginning this scene with

REGAN. Hang him instantly. 
contrasts the cruelties of the two sisters with all possible brutality (Tate cuts Goneril from the scene). Nor has any critic of Tate's version noted the starkly transparent one-upmanship in Tate's source here, Goneril producing a more imaginative and poetic punishment than her little sister. In Shakespeare, the irony of Regan's supporting not her own punishment but that suggested by Goneril and carried out by Regan's husband Cornwall is blatant (perhaps Tate saw that there must be an unspoken subtext in Cornwall's accepting his sister-in-law's punishment for Gloucester over his wife's suggestion). It is not Tate but Shakespeare who magnifies the evil of the sisters to the furthest possible degree.

In fact, far from darkening the sisters further, Tate complicates and humanizes Regan by artfully altering her lines. Immediately following the gouging out of the first of Gloucester's eyes, Tate cuts Shakespeare's terrible insistence on the necessity of the human body's bilateral symmetry: 'one side will mock another. Th' other too' (3.7.74). He thus anticipates at least one recent Lear production in which Regan turns away in disgust from the actual blinding. ${ }^{17}$ More subtly, Tate gives her two highly suggestive lines after Cornwall is wounded: at the servant's interference, her line suggests a sudden subtextual excitement: 'Help here - are you not hurt, my lord?' (3.5.54). The contrast between the public call for assistance (perhaps it is not very loudly delivered) and the private and intimate question about her spouse's physical injury combine to yield a sense of quick discovery, the implications of the 'not' clear if we omit the word. In contrast, Shakespeare's repetition implies Regan's genuine concern: 'How is't, my lord? How look you?' (3.6.97), Tate a briefer, more bleakly imagined 'How is't, my lord?' ['how is that wound coming along?'] (3.5.63), from a Regan who already knows how it is, and who is already thinking forward to replacing her dying husband with Edmund. In these respects, Tate's script affords more scope for richly ironic acting than does Shakespeare's. As Adler points out, Tate's version of the script ultimately influences even Kosintsev's film, where at Cornwall's 'give me your arm,' Regan does not, Cornwall realizes the significance of her refusal, Regan waits till he falls, 'then turns and runs to Edmund's room, throws open the door, grasps his shirt on either side, and bares him to the waist.' (55).

The tradition of not reading Tate's script in its historical or theatrical context but of using his version merely as negative example continues. In his primarily political approach, Michael Dobson glances at Cordelia's 'bourgeois sensibility. ${ }^{18}$ In order to argue for Tate's oversimplification of his source, Jean Marsden must take an ingenuous view of Shakespeare's drama: 'Tate's Edmund dies as entrenched in evil as he lived; unlike Shakespeare's villain who gasps out "some good I mean to do, / 
Despite of mine own nature" ... he dies unrepentant.$^{19}$ But I think that Tate sees that in Shakespeare's script, there are over ninety lines after Edmund's fatal wounding and before his 'some good I mean to do' speech, plenty of time to stage a 'last-gasp' speech; Tate knows how long it usually takes the wounded to die onstage. Even Hamlet lives for only fifty-four lines of script; Mercutio in Romeo and Juliet for eighteen; and Hotspur in I Henry IV lives for merely ten. Though Tate cuts this apparent conversion, he does not alter Shakespeare but follows him in keeping Edmund unrepentant. He sees that Shakespeare's dramatic strategy in the 332-line-long last scene is one of delay, so that ignorance of developments up to that point makes it impossible for the long succession of characters coming onstage to ask the question the audience is dying for them to ask: where are Cordelia and Lear? Further, Tate sees, in the words of James P. Lusardi, that Shakespeare uses Edmund as 'the most consciously skillful actor and improviser of such fictions that we encounter, beginning with the elaborate deceptions he perpetrates on both father and brother in 1.2. ${ }^{20}$ In sharp contrast to Tate, it is recent critics who take Edmund at his word, even though to do so requires Edmund's sudden loss of his habitually impeccable sense of timing:

Edmund's belated effort to save the life of Cordelia, though unsuccessful, suggests that this intelligent villain has at last begun to understand the great flaw in his naturalistic creed and to see that, like Goneril and Regan, he has been consumed by his own lust. (Bevington, 1171)

This against the unacknowledged evidence of the ninety-line gap.

Edmund begins to spin out his own final act just a few lines after Edgar wounds him:

What you have charged me with, that have I done,

And more, much more. The time will bring it out.

'Tis past, and so am I. (5.3-165-7)

At his 'more, much more' in the Kosintsev film, though Edmund is writhing in a pool of his blood, he grins at the camera; Kosintsev treats this scene as a staged extension of the action as directed by Edmund. ${ }^{21}$ In order to forestall the queries about Lear and Cordelia which Edmund knows these words will produce, he hastens to add, 'But what art thou / That hast this fortune on me?' (165-66) and, in response to Edgar's answer, which consists of a long narrative of their father's history and death, he again speaks to delay Edgar's and Albany's questions about the fate of Cordelia and Lear, going so far as to substitute the role of playwright for that of character: 'This speech of yours hath moved me, 
/ And shall perchance do good. But speak you on [emphasis added]; / You look as you had something more to say' (203-05).

In Shakespeare the dead sisters are brought onstage, and only then does Edmund, perhaps after a final glance at his watch, knowing that it is too late, produce the final lie, gross and palpable to the audience and to Tate:

I pant for life [he has said, 'tis past, and so am I']. Some good I mean to do,

Despite of mine own nature. Quickly send -

Be brief in it - to th' castle, for my writ

Is on the life of Lear and on Cordelia.

Nay, send in time. (248-52)

While Shakespeare brings the dead sisters onstage just before this speech, Tate - in a change much critically lamented - at Edmund's defeat, has Goneril and Regan cry 'save him, save him' (5.5.58). While he is dying, they have a jealous set-to about who deserved the Bastard's love, and they then reveal that they poisoned one another the night before. Yet there is a stage effectiveness as well as a psychological truth in Tate's version, for desire does proverbially last till death. ${ }^{22}$ Tate shares the Shakespearean vision: Edmund himself is 'unrepentant' in both plays. The expectation that in the Bard's version no character can persist in villainy is undercut on the plain evidence of Shakespeare's script because from the start, Edmund has enjoyed stage-managing: his third line in the play is 'Sir, I shall study deserving' (1.1.31).

Indeed, Tate has throughout his revision concentrated on the virtuosic self-consciousness of Edmund's villainy, accordingly beginning his play with Edmund's 'Thou, Nature, art my goddess; to thy Law / My services are bound.' Edmund fully explains his intentions, and in Tate's revision, both old fathers have been deluded about Edgar/Edmund before the action begins; accordingly, Lear can see in Cordelia's silence an echo of what he already believes to be Edgar's treachery:

\section{I perceive}

The truth of what has been suggested to us:

Thy fondness for the rebel son of Gloster,

False to his father, as thou art to my hopes. (1.1. 118-21)

Because he begins his version with Edmund's soliloquy, Tate then modifies the Shakespearean version by having Kent and Gloster enter, but their topic is not rumours about the Court as to whether Lear favours Cornwall or Albany (Tate cuts this topic) but rather their discussion about the perfidy of Edgar. And in this early passage, Tate again moves 
not merely to simplify but to develop: his script leaves it open whether Kent is convinced by Gloster, just as Shakespeare has left equal room for whether Lear prefers Albany or Cornwall. Tate next takes advantage of his modifications of the play's beginning by using the Kent-Gloster discussion to lead into:

KENT. I grieve to see him

With such wild starts of passion hourly seized,

As renders majesty beneath itself.

GLOSTER.

Alas! 'tis the infirmity of his age.

Yet has his temper ever been unfixed,

Choleric and sudden - Hark, they approach. (1.1.50-55)

In Shakespeare, Goneril and Regan make similar comments (1.1. 292$304)$, but only after Lear has confirmed himself in his enormous misjudgement.

Those who accuse Tate of oversimplifying, of smoothing over complexities, ignore the fact that both scripts frequently call attention to their own egregious over-simplifications, Tate retaining, for example, Edgar's easy assumption of fair retribution for Gloucester's adultery in conceiving Edmund: 'The dark and vicious place where he begot thee / Cost him his eyes' (5.5.42-43; in Shakespeare 5.3.175-76). No experienced theatregoer or reader would take Edgar's comforting interpretation to express Shakespeare's own personal opinion on the inevitability of retributive justice in this world; it is equally important that when a dramatic character in Tate expresses an idea it is not necessarily intended as a transcript of his conception of reality.

Although Tate's notorious last scene (5.6) must be acknowledged Lear and Cordelia in prison, approached by murderers - Lear kills two onstage, before Albany and Edgar arrive for the rescue - Kent is brought in, and next, in Albany's words, 'Look ... where pious Edgar comes / Leading his eyeless father' (111-12) - we hear that Edmund and Goneril and Regan are dead - Lear presents Edgar with his bride - decides that he and Kent and Gloster will retire 'to some cool cell' (147), and Edgar makes a final speech about Peace and Plenty. Yet in some respects, Tate has gone about the business of reading the older scripts he is revising in a spirit mercifully free of the sentimental bardolatry which still afflicts some critics. In rewriting and resiting the Lear story, Tate finds that Shakespeare's Regan is too vicious and that Edmund actively enjoys the state of gracelessness and loves to act to delude others, and he builds upon these perceptions. Contemporary critics still have a rage for order- 
ing texts, and are willing to privilege the Shakespearean ones at any cost even if it means praising his scripts rather than reading them.

\author{
JOHN REMPEL \\ University of Manitoba
}

\title{
Endnotes
}

1 The Spectator, No. 40 (16 April 1711) in Joseph Addison, The Works (London: Tonson, 1721) 2:486; Michael Dobson, The Making of the National Poet: Shakespeare, Adaptation and Authorship, 1660-1769 (Oxford: Clarendon Press, 1992) 82. I would like to thank Lumen's anonymous reader for acute and pointed commentary on an earlier version of this essay.

2 Nahum Tate, The History of King Lear, ed. James Black (Lincoln: U of Nebraska P, 1975) xv. Future references to this edition will appear within parentheses in the text.

3 In the 1995-96 academic year, W. Bronnimann of the University of Basel's English Department devoted a course to 'Rewriting Shakespeare: Versions of King Lear.'

4 'Nahum Tate is Alive and Well: Elijah Moshinsky's BBC Shakespeare Productions,' Shakespeare on Television, ed. J. C. Bulman and H. R. Coursen (Hanover: UP of New England, 1988) 199. Moshinsky produced All's Well That Ends Well, Midsummer Night's Dream, Cymbeline, Coriolanus and Love's Labour's Lost.

5 The Textual Condition (Princeton: Princeton UP, 1991) 10.

6 King Lear (Bristol: Bristol Classical P, 1987) 1.

7 'The Half-Life of Tate in King Lear," Kenyon Review 7 (1985): 52-3. Future references to this essay will appear within parentheses in the text.

8 Bratton 2.

9 William Shakespeare, King Lear in The Complete Works of Shakespeare, ed. David Bevington, 4th ed. (New York: HarperCollins, 1992) 5.6.147. Future references to this edition will appear within parentheses in the text.

10 D. C. Greetham, Textual Scholarship: An Introduction, 2nd ed. (New York: Garland, 1994) 319.

11 See, for example, Eric S. Ristad's review of a Riverside Shakespeare Company production of Tate's play, 'Excellent production of butchered King Lear,' The Tech 9 (1985) WWW document.

12 Bevington, A-47.

13 For convenience, I refer to Shakespeare's play as if it were fully represented by one text, although the earliest printing, the quarto of 1608 , is revised (we do not know by whom) to sharply darken the vision of the 1623 folio: the quarto counterbalances Cornwall and Regan's onstage blinding of Gloucester by the second and third servants' speeches: 'I'll never care what wickedness I do, / If this man [Cornwall] come to good,' and 'I'll fetch some flax and whites of eggs / To apply to his bleeding face' $(3.7 .101-02,109-10)$. These pointed kindnesses are 
cut in the folio, cuts which became famous when Peter Brook followed the folio in his 1970 film.

14 Samuel Johnson: Selected Writings, ed. Patrick Cruttwell (Harmondsworth: Penguin, 1968) 281.

15 The Re-Imagined Text: Shakespeare, Adaptation, \& Eighteenth-Century Literary Theory (Lexington: UP of Kentucky, 1995) 20 (emphasis added).

16 Perf. King Lear, dir. Jonathan Miller (BBC/Time-Life, 1982).

17 Nanette Jaynes, Review of King Lear, dir. Tim Ocel, Georgia Shakespeare Festival, Atlanta, Shakespeare Bulletin 13 (Fall 1995): 25.

18 Dobson 84.

19 Marsden 28-9 (my emphases).

20 'Lear's Mock Trial,' Shakespeare on Television 131.

21 King Lear, dir. Grigori Kosintsev, script by Pasternak, music by Shostakovich, 1971.

22 Compare Pope's Epistle to Cobham:

The Manor, Sir? - 'The Manor! hold,' he cry'd,

'Not that, - I cannot part with that' - and dy'd (260-61) and

'One would not, sure, be frightful when one's dead-

And-Betty-give this Cheek a little Red.' (246-47)

The Poems of Alexander Pope, ed. John Butt (London: Methuen, 1963). 